\title{
Visa Regulation of Indonesian Migrant Worker Based on Immigration Control Act of Japan, 2018
}

\author{
Darminto Hartono $^{1^{*}}$, Lapon Tukan Leonard ${ }^{2}$ \\ ${ }^{1}$ Lecture at Faculty of Law Diponegoro University, Semarang 50275, Indonesia, \\ ${ }^{2}$ Lecture at Faculty of Law Diponegoro University, Semarang 50275, Indonesia
}

\begin{abstract}
Japan as a developed country needs a lot of productive labor to fulfill its human resources needs. With the revised Immigration Act of 2018, Japan has opened up to accept many migrant workers, one of whom is Indonesian migrant worker who can fulfill these needs. The purpose of this research is to find out the form of visa regulation for Indonesian migrant workers in Japan based on the provisions of the Japan Immigration Act 2018 and to know the efforts of the Indonesian Government can make in implementing the visa regulations to facilitate Indonesian migrant workers who will work in Japan.
\end{abstract}

Keywords: Japan, Indonesia, Visa, Immigration, Control, Act.

\section{Introduction}

Japan and Indonesia have a mutually beneficial cooperation program on both sides, namely the cooperation of Indonesian migrant workers in Japan. The Japan - Indonesia cooperation program was formed because of the abundance of productive human resources in Indonesia that has been equipped with the ability in the field of verified engineering to be able to work in labor-deprived Japan for the lower middle class. Indonesian migrant workers will be needed to facilitate development in Indonesia and can be a means of cooperation with Japanese medium and small companies in Indonesia. Indonesian migrant workers in Japan are more commonly known as Indonesian Interns or in Japanese called Kenshuusei (practicing while working) and Jishuusei (working while practicing). These workers require a work visa in Japan based on the Japanese company's employment contract with the individual. For foreign nationals, to enter a country requires an entry permit or so-called Visa.

\section{Corresponding Author: \\ Darminto Hartono}

Lecture at Faculty of Law Diponegoro University, Semarang 50275, Indonesia

e-mail: darmintohartono.undip@gmail.com
With the new visa regulations, Indonesian migrant workers are distinguished by Specific Skilled Worker Visas (PBS) and Technical Internship Training Visas (PMT). The new PBS visa was passed through the latest regulations in April 2019 with the aim of meeting the needs of human resources in Japan to work a minimum of 5 (five) years or without the required time span. In addition, PBS also has only 16 jobs that can be applied for visas, in contrast to PMT which has 16 jobs. A very clear difference, PBS visas do not require migrant workers to be training before entering a routine job in Japan, but it does relate to having to pass migrant workers in skill tests and Japanese language tests.

\section{Method}

The main purpose is to find answers to various problems that arise in society is to conduct a research. Research in fact reveals something systematically, methodologically and consistently so that the results of the research should be accountable ${ }^{1}$ Research on Visa Regulation of Indonesian Migrant Worker Based on Immigration Control Act of Japan, 2018 legally binding protection provided by the State with the guidance of the regulation. This study uses data analysis approaches and normative juridical method. It uses descriptive analysis method by using literature, documentary studies and field research related to the primary substance of this study. After the data has been collected, the next process is to 
identify, clarify and analyses systematically. Finally, all research results are presented in a compiled final report.

\section{Results and Discussion}

Each country has sovereignty of the country which means the highest power for the state to freely conduct various activities in its interests as long as the activity does not conflict with International Law. An important limitation of a country's sovereignty is that it is limited to the territorial boundaries of the state and that power ends where the power of another country begins. It is clear that understanding the sovereignty, independence and equality of the above countries does not contradict the concept of an International Society governed by International Law, it can even be said that if it is reasonably understood this sovereignty with two understandings that align with it namely the independence and equality of the degrees of countries is an understanding that has a very important function in realizing an International Society governed by International Law as a reality. ${ }^{2}$.

To safeguard the sovereignty and power of the state within the boundaries of its territory, each country has jurisdiction. The jurisdiction of this country is essentially inseparable from the concept of territorial sovereignty of a country which is one of the essential attributes of the state. Countries exercising sovereignty on their territory will be allowed to make their own laws and regulations legally binding on their residents living on their territory including their owners ${ }^{3}$.State accountability as well as with individuals who may give rise to the country's rights and obligations to foreigners, nationality, extradition, and asylum, as well as human rights.

All countries have the authority and power to accept or reject foreigners on their territory. If a country accepts the entry of foreigners into its territory, it will grant a visa granted by the country through the embassy of the receiving country located in the country. Through such visas, foreign nationals in the destination country have certain rights and obligations. Foreign nationals obtain the right of acceptance of the destination country followed by obligations to comply with local laws and regulations, so-called provisional compliance terms ${ }^{4}$.

There are several opinions regarding the entry of foreigners to the destination country: All states are obliged to grant permission to all foreigners; A state is obliged to grant permission to all foreigners, provided that it has the right to reject certain groups, such as drug addicts, certain people with certain diseases and other unwanted persons; A state is bound to allow foreigners to enter but may impose conditions relating to their entry permit, and; A state has the right to ban all foreigners according to its will ${ }^{5}$.

In International Law, there is a Theory of Social Contract that states that a person who is in society is outside and regardless of state power. This theory was then applied and analyzed against the state that a country engaged in the association of the International Community, the basic right is not separated from the influence of another country. Further development is influenced by the Natural Law which gives rise to the doctrine of inter-state relations and human relations is the same, namely the right to mutual respect, equality of rights and independence. The American Institute of International Law (AIIL) produced the Declaration of the Rights and Duties of Nations, which was followed by a study of fundamental right and duties of American Republics until the completion of the 1933 Montevideo Convention.

In International Law a country has a standard of treatment of foreigners, i.e. ${ }^{6}$ :

a. National Treatment Standards: According to national treatment standards foreigners should be treated the same as citizens of the destination country, which if applied consistently would benefit foreigners. International Law does not govern the country's treatment of foreigners in all activities. The disadvantage of the country's national treatment standards can certainly treat foreigners inhumanely and justify such treatment on the basis that its citizens can be treated equally.

b. International Minimum Standard: According to international minimum standards it stipulates that countries must offer the same treatment of foreigners as their citizens enjoy, but such treatment should not be less than the human rights recognized in international instruments.

In principle each country will be responsible for providing legal protection to every citizen wherever it is and foreigners will receive legal protection under certain restrictions both from the country in which it is located and from its home country. Thus, the nationality status of a person is closely related to the protection of International Law to be given to him, against him, property and his family ${ }^{7}$.

Japan's 2018 immigration oversight law, which 
came into force in April 2019, is a new law that has been passed from several parts of the Immigration and Refugee Control Act. The revised law includes new rules, including visa rules for migrant workers. As part of this framework, Japan established migrant worker visas for the 'professional skilled workers' category.

The Life of Foreign Workers in Japan: Foreign workers living in Japan as many as 1.28 million. This is a record after there were 480,000 foreign workers in Japan in 2008 . However, the figure is only $1 \%$ compared to Japan's population. Nearly $30 \%$ of Japan's foreign workers come from China with significant populations from Vietnam, the Philippines and Brazil ${ }^{8}$. While in 2019, the number of foreign workers in Japan rose $13.6 \%$ from the previous year to $1,658,804$ people. China accounted for about a quarter of all foreign workers at 412,327, followed by Vietnam at 401,326 and the Philippines 179,685 , according to the Ministry of Health, Labor and Welfare 9 . This increase appears to be due to the government's promotion of the involvement of highly skilled foreign workers, exchange of students and intern trainees in the workforce, as well as improvements in the overall employment situation leading to more hiring permanent residents and spouses of Japanese citizens ${ }^{10}$.

\section{Ratio of Foreign Workers by Nationality}

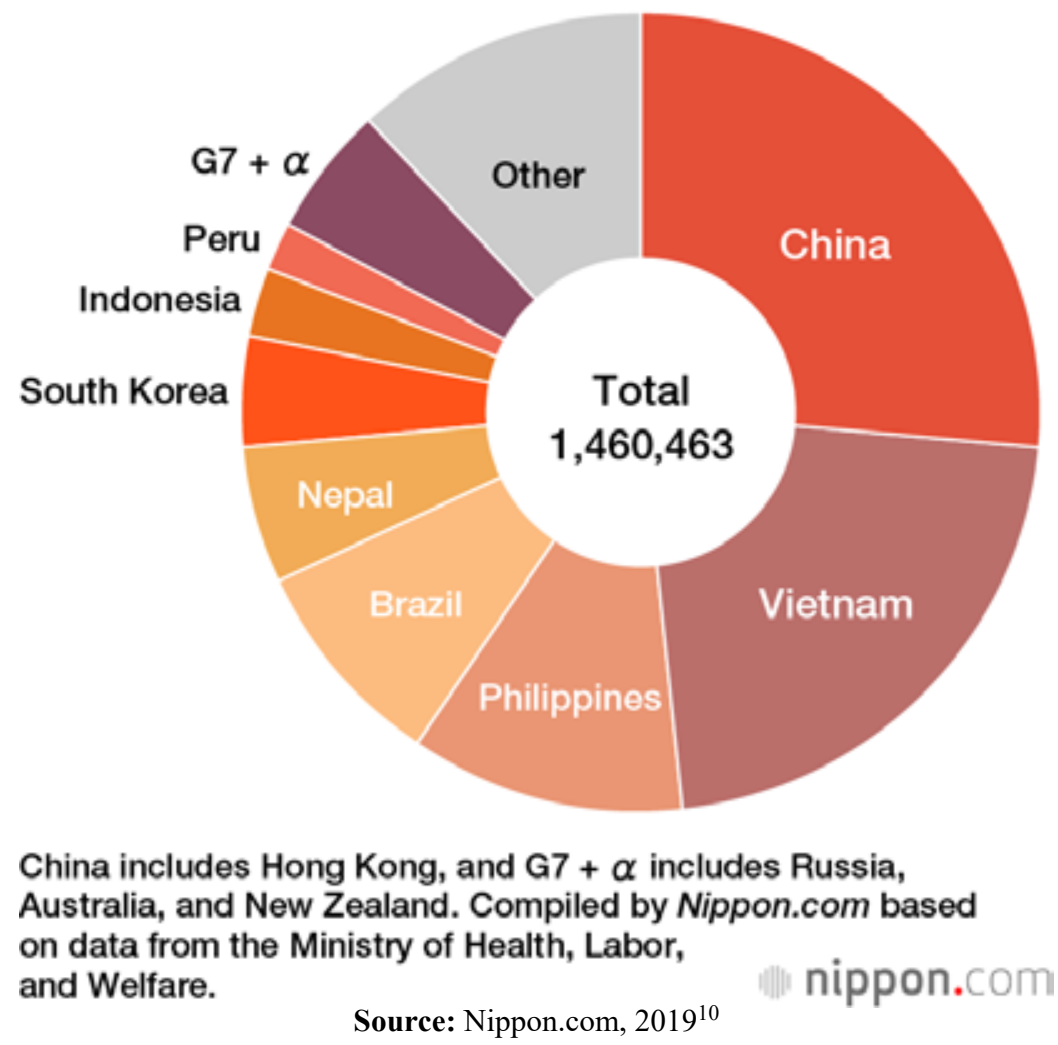

Figure 1. Ratio of Foreign Workers by Nationality

Indonesian migrant workers alone in Japan recorded 49,982 people living in Japan both legally and illegally. Since 1998, the chairman of the factory association in Oarai has invited Japanese descendants and migrants from North Sulawesi to work in the seafood industry, so it is not new that many Indonesian migrant workers in Japan today ${ }^{11}$.According to statistics from the Indonesian Migrant Workers Protection Agency, Japan received 486 Indonesian migrant workers in 2019. The figure decreased from 538 in 2017, which makes Japan number 13 for the largest Indonesian migrant worker placement country.

Arrangement of Worker Visa under Japan Immigration Control Act 2018: After the Second World War, Japan's labor management system was 
reorganized and new labor laws were introduced along democratic lines. The "Employment Law" includes detailed regulations on the realization of labor relations and modern and democratic labor practices. In the 1960s, the labor market changed significantly. Although agricultural residents flocked to the industrial sector, labor shortages were first seen around 1959. With Japan's rapid economic development, the slow growth of the production age population in Japan, and the growing number of young people going to high school and university instead of looking for work, the availability of productive people in Japan is very limited.

According to Professor Hiroshi Yoshida, an economist at Tohoku University in Japan published in the Daily Mail on May 13, 2012 ${ }^{12}$ : "Birth rates are starting to show an alarming decline since 1975. In terms of the number of births, this indicates that the age of children in the current 14 -year population reaches 16.6 million, and this number decreases by one (1) person every 100 seconds. Recent studies have shown that Japan's population is expected to become extinct within 1,000 years if left unchecked."

To find a solution to the problems facing Japan today, namely the deterioration of the Japanese economy, low competitiveness, reduction of productive labor force, and increasing the number of elderly populations is an interconnected problem. Japan believes that it is necessary to serve the lower middle class immediately. Give me the manpower,by introducing workers from abroad, especially those from developing countries such as Indonesia. Other issues that arise are Japan's Employment and Employment Law and Immigration Law, which cannot be changed automatically. For the fulfillment of the foreign workforce, the Japanese government adheres to the term apprenticeship program (kenshuusei-jisshuusei). Since 1994 there has been a Memorandum of Understanding (MoU) between the Directorate General of The Ministry of Foreign Affairs and The Association for International Manpower development of Medium and Small Enterprises Japan (IMM).

According to international law, Japan has applied several exceptions to the influx of foreigners, one of whom is poor or has no permanent residence, and can be a burden for the Japanese government or public bodies due to their inability to make a living. Therefore, in accordance with current regulations, any foreign workers with certain professional knowledge can give him the opportunity to stay and work long term in accordance with the period of the contract that can be extended.

Visa arrangements for foreign workers in the latest law make up the difference between interns and workers with special skills. Interns (Kenshuusei) are part of a work training system organized in an integrated way between training in training institutions by working directly under the guidance and supervision of instructors or workers who are more experienced in order to master certain skills or skills. While workers with special skills (Specified Skilled Worker/Tokutei Ginou) are workers who will work in certain fields in accordance with the certificate of expertise or Certificate of Japanese language owned from their country.

The granting of work visas to foreign workers began to be distinguished by the Japanese Government after the revised regulations. Special Type 1 skills are open only to those with adequate technical and Japanese skills. Special Type 2 skills are given to workers working in construction and shipbuilding. Only type 2 visas are allowed to bring their spouses and children to Japan. Information on the rules of residence of foreign workers in Japan, explained article 2-2 of Immigration Control and Refugee Recognition Act (Cabinet Order No. 319 of October 4, 1951) namely:

\section{Article 2-2:}

(1) Except as otherwise provided in the Immigration Control and Refugee Recognition Act and other laws, a Foreign National is to reside in Japan under the status of residence (in the case of the status of residence of "Highly Skilled Professional", including the category of item (i), sub-items (a) through (c) or item (ii) listed in the right-hand column under "Highly Skilled Professional" of Appended Table I (2); in the case of the status of residence of "Specified Skilled Worker", including the category of item (i) and (ii) listed in the righthand column under "Specified Skilled Worker" of the same table; in the case of the status of residence of "Technical Intern Training", including the category of item (i), sub-item (a) or (b), item (ii), sub-item (a) or (b) or item (iii), sub-item (a) or (b) listed in the right-hand column under "Technical Intern Training" of the same table; the same applies hereinafter) associated with that Foreign National's permission for landing, under the status of residence that the Foreign National has acquired, or under the 
status of residence following a change to either of these.

(2) The categories of status of residence are to be as listed in the left-hand column of Appended Table I (in the case of the status of residence of "Highly Skilled Professional", including the category of item (i), sub-items (a) through (c) or item (ii) listed in the right-hand column under "Highly Skilled Professional" of Appended Table I (2); in the case of the status of residence of "Specified Skilled Worker", including the category of item (i) and (ii) listed in the right-hand column under "Specified Skilled Worker" of the same table; in the case of the status of residence of "Technical Intern Training", including the category of item (i), sub-item (a) or (b), item (ii), sub-item (a) or (b) or item (iii), sub-item (a) or (b) listed in the right-hand column under "Technical Intern Training" of the same table; the same applies hereinafter) and II. A Foreign National residing in Japan under a status of residence listed in the left-hand column of Table I may engage in the activities listed in the right-hand column corresponding to that status, while a Foreign National residing under a status of residence listed in the left-hand column of Table II may engage in the activities of a person with the status or position listed in the right-hand column corresponding to that status.

(3) The period during which a Foreign National may reside as set forth in paragraph (1) (hereinafter referred to as "Period of Stay") is determined for each status of residence by Ministry of Justice Order; and when the status of residence is one other than that of "Diplomat", "Official", "Highly Skilled Professional" or "Permanent Resident" (in the case of the status of residence of "Highly Skilled Professional", limited to those pertaining to item (ii) in the right-hand column under "Highly Skilled Professional" of Appended Table I (2)), the Period of Stay does not exceed 5 years.

The application processes and documents required to apply for a worker visa with the latest conditions are:

a. Application to the Regional Immigration Services Bureau

- Applicants must submit a form for issuance of a certificate of eligibility in accordance with the individual's professional expertise for residency status.
- The applicant must submit a point's assessment form relating to the activity to be carried out and documentary evidence of the points.

b. Checks by the Immigration Services Agency

The examination of requirements is regulated in accordance with Article 7 paragraph (1) of item (ii) of the Immigration Control Act, namely: "Article 7 (1) When the application set forth in paragraph (2) of the preceding Article is made, an Immigration Inspector must conduct an examination of the Foreign National as to whether or not the Foreign National conforms to each of the following conditions for landing in Japan (with respect to a person who has been granted reentry permission pursuant to the provisions of Article 26, paragraph (1) or a person who possesses a Refugee travel document issued pursuant to the provisions of Article 61-2-12, paragraph (1), only the conditions listed in the following items (i) and (iv) are to be applied): (i) the Passport possessed by the Foreign National and the visa affixed thereto, if such is required, must be valid."

c. Issuance of certificate of eligibility: If the eligibility certificate requirements have been approved, foreign nationals can obtain visas and permission to land smoothly by presenting a certificate of eligibility when applying for a visa.

\section{Conclusion}

Japan revised, added and updated the Immigration Supervision Act 2018 primarily on visa arrangements for migrant workers or Foreign Workers who will work in the country. With the revision, other countries including Indonesia also feel the benefits and interest to be able to send migrant workers to Japan. There is a reciprocal interest between Japan and Indonesia; Japan lacks many productive middle-class workers to meet the needs and demands of its companies, while Indonesia has many productive-age workers who are expected to meet Japan's quotas or the amount needed. This change in Japanese government policy demonstrates an open attitude towards other countries by accepting foreign workers to enter and participate in the development of their country. In the previous law Japan only applied admission to interns (Kenshuusei/Jishuusei) for 3 (three) to 5 (five) years, while the new Immigration Supervision Act applies the provision of residence visas for migrant workers if they fall into the category of skills and meet the conditions mentioned.Efforts can be made by the Government of Indonesia in implementing the new visa 
arrangements by Japan, namely by carefully preparing adequate facilities and infrastructure for prospective Indonesian migrant workers. The Government of Indonesia and the Government of Japan, in this case the Japanese Embassy in Indonesia, immediately prepared technically the terms and conditions that must be met for prospective Indonesian migrant workers to Japan. Then the Government of Indonesia is obliged to conduct optimal coaching and supervision to the officers in order to be more professional in handling, educating and training prospective Indonesian migrant workers to comply with the applicable terms and conditions in Japan (Receiving Country).

Conflict of Interest: There is no conflict of interest.

Source of Funding: This research was funded by the Diponegoro University Faculty of Law Research Grant Fund for the 2020 Fiscal Year.

Ethical Clearance: Ethical clearance from the institutional ethical committee obtained for the study.

\section{References}

1. Soekanto S, Mamudji S. Normative Legal Research [Indonesian], Jakarta: Raja Grafindo Persada. 1985.

2. Hardiwinoto S, International Law Textbook [Indonesian]. Semarang: Universitas diponegoro. 2014.

3. Suryokusumo S. International Law Case Studies [Indonesian], Tangerang: Tatanusa. 2007.

4. Hardiwinoto S, Persada AGK. Legal Protection of Indonesian Migrant Workers (TKI) Abroad (Country Practice: Saudi Arabia, Hong Kong, Japan, Korea, Malaysia, Singapore and Taiwan) [Indonesian], Semarang: Badan Penerbit Universitas Diponegoro. 2018.
5. Starke JG. Introduction to International Law [Indonesian], Jakarta: Sinar Grafika. 2001.

6. Wallace RM, Arumanadi B. International law [Indonesian], Semarang: IKIP Semarang Press. 1993.

7. Arsensius A. Perlindungan Orang Asing dalam Hukum Internasional. Jurnal Varia Bina Civika, 2009;75. Available: https://jurnal.untan.ac.id/ index.php/civika/article/view/399.

8. Lufkin B. More seniors, more foreigners: How Japan is changing. BBC Worklif.11 Dec 2018. Available: https://www.bbc.com/worklife/ article/20181210-more-seniors-more-foreignershow-japan-is-rapidly-changing. Accessed 27 May 2020.

9. Kyodo K. Number of Foreign Workers in Japan Totals Record 1,66 Million. The Japan Times.32 Jan 2020 Available: https://www.japantimes.co.jp/ news/2020/01/31/national/foreign-workers-japanrecord/\#.Xs4Iy2gza00.Accessed 27 May 2020.

10. Nippon.com.Record 1,46 Million Foreign Workers in Japan. 6 Feb 2019. Available: https://www. nippon.com/en/japan-data/h00382/record-1-46million-foreign-workers-in-japan.html.Accessed 27 May 2020.

11. Mutiara M. Noise Complaints between Japanese Neighbors and Migrants in Rural Japan: From the Perspectives of Noisemakers. Social Sciences. 2018;7(12):268.

12. Oliver A. Falling birth rates mean Japan 'won't have any children under 15 by 3011'. Daily Mail. 13 May 2012. Available: https://www.dailymail. co.uk/news/article-2143748/Falling-birth-ratesmean-Japan-wont-children-15-3011-current-trendcontinues.html. Accessed 28 May 2020. 